
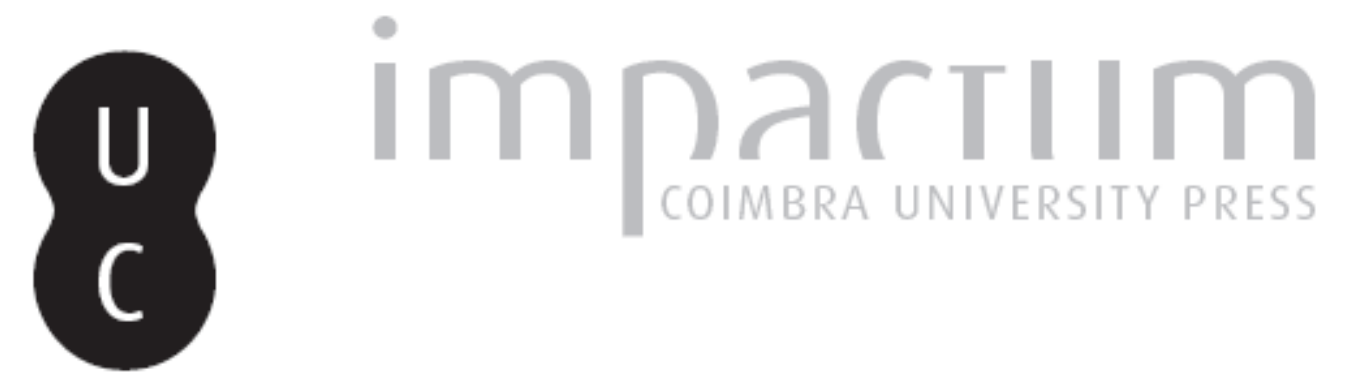

\title{
Considerações acerca da movimentação em massa ocorrida na vertente poente da Ava. Elísio de Moura, em Coimbra
}

Autor(es): $\quad$ Lourenço, Luciano; Lemos, Luis J. L.

Publicado por: Associação Portuguesa de Riscos, Prevenção e Segurança

URL persistente:

URI:http://hdl.handle.net/10316.2/40103

DOI:

DOI:https://doi.org/10.14195/1647-7723_8_8

Accessed : $\quad$ 26-Apr-2023 14:24:26

A navegação consulta e descarregamento dos títulos inseridos nas Bibliotecas Digitais UC Digitalis, UC Pombalina e UC Impactum, pressupõem a aceitação plena e sem reservas dos Termos e Condições de Uso destas Bibliotecas Digitais, disponíveis em https://digitalis.uc.pt/pt-pt/termos.

Conforme exposto nos referidos Termos e Condições de Uso, o descarregamento de títulos de acesso restrito requer uma licença válida de autorização devendo o utilizador aceder ao(s) documento(s) a partir de um endereço de IP da instituição detentora da supramencionada licença.

Ao utilizador é apenas permitido o descarregamento para uso pessoal, pelo que o emprego do(s) título(s) descarregado(s) para outro fim, designadamente comercial, carece de autorização do respetivo autor ou editor da obra.

Na medida em que todas as obras da UC Digitalis se encontram protegidas pelo Código do Direito de Autor e Direitos Conexos e demais legislação aplicável, toda a cópia, parcial ou total, deste documento, nos casos em que é legalmente admitida, deverá conter ou fazer-se acompanhar por este aviso.

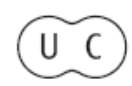




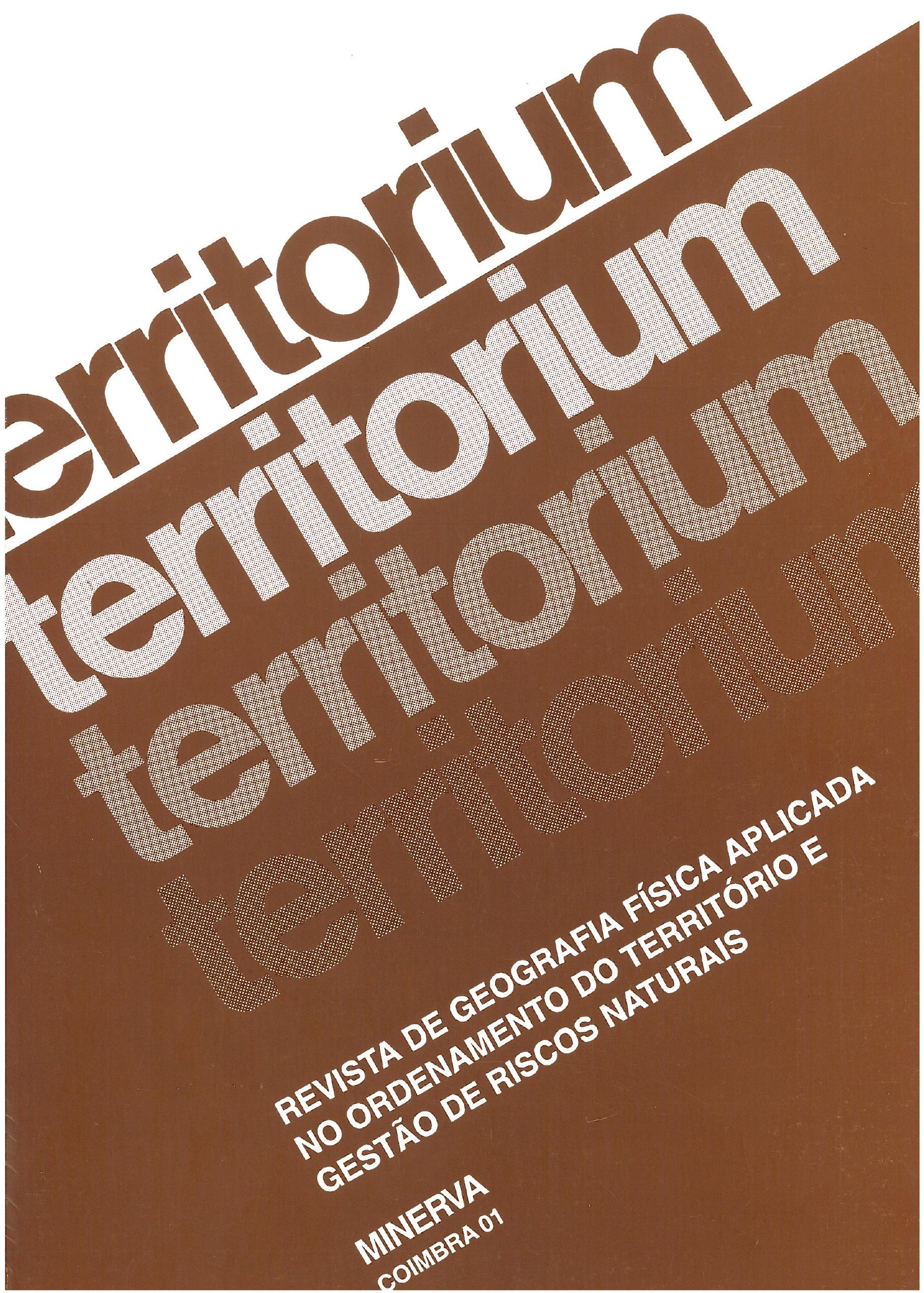




\title{
Considerações acerca da movimentação em massa ocorrida na vertente poente da $\mathrm{Av}^{\mathrm{a}}$. Elísio de Moura, em Coimbra
}

\author{
Luciano Lourenço* \\ Luis J. L. Lemos ${ }^{* *}$
}

\begin{abstract}
Resumo:
No Inverno de 1997, ocorreu no local um esboço de deslizamento, na sequência do qual foram efectuadas algumas obras de estabilização da vertente, que muito aumentaram a segurança de toda a encosta.

Cerca de três anos depois, no dia 27 de Dezembro de 2000, registou-se novo deslizamento no mesmo local, situadoentre a Rua António Jardim e as traseiras dum prédio com 16 andares, o $n^{\circ} 339$ da Av $^{2}$ Elísio de Moura. Este deslizamento movimentou um volume de terras avaliado em cerca de $4000 \mathrm{~m}^{3}$, afectando uma área com cerca de $120 \times 60 \mathrm{~m}$ e com, aproximadamente, $50 \mathrm{~m}$ de desnível, tendo arrastado o respectivo coberto vegetal, constituído essencialmente por eucaliptos de grande porte.

Esta movimentação ficou a dever-se, por um lado, a intervenções antrópicas na vertente e, por outro lado, às precipitações anormais que antecederam o evento.

Palavras chave:

Coimbra, deslziamentos
\end{abstract}

\section{Résumé:}

Au cours de l'hiver de 1977, des indices de glissement se sont fait sentir dans le local et par suite on a fait quelques travaux visant la stabilisation du versant ce qui a beaucoup amélioré la sécurité de ce coteau.

Environ trois ans après, lle 27 décembre 2000 , un nouveau glissement s'est enregistré, dans le même local, situé entre la Rue António Jardim et les derrières d'un immeuble de 16 étages, le nº 339 de l'Avenue Elísio de Moura.

Ce glissement a mouvementé un volume de terres estimé à environ $4000 \mathrm{~m} 3$, en affectant une aire d'environ $120 \times 60 \mathrm{~m}$, avec un dénivellent d'environ 50 mètres et entraînant dans son cours la respective couverture végétale constituée, essentiellement, par des eucalyptus de grande taille. Ce glissement se doit, d'une part aux interventions anthropiques dans le versant et d'autre part aux précipitations anormales qui ont précédé l'événement.

Mots clés:

Coimbra, glissements

\section{Abstract:}

In the winter of 1997 , a signs of a landslip occurred, which resulted in stabilisation work being carried out on the slope, greatly increasing the safety of the whole hillside.

About three years later, on 27 December 2000, there was another landslip in the same place, between Rua António Jardim and the back of a 16-floor apartment block, $n^{\circ} 339$, on the Avenida Elísio de Moura.

This landslip shifted a mass of earth calculated to be around 4000 cubic metres, affecting an area of approximately $120 \times 60 \mathrm{~m}$, with a drop of almost $50 \mathrm{~m}$, dragging with it the covering vegetation, which consisted mainly of large eucalyptus trees.

The slippage was caused on the one hand by human activity on the slope and, on the other, by the abnormal rainfall that preceded the event. Key words:

Coimbra, landslips

\section{Introdução}

Ainda não completamente refeitos dos trágicos acontecimentos ocorridos em Arcos de Valdevez (A. S. PEDROSA, L. LOURENÇO e J. FELGUEIRAS, 2001), eis senão quando a comunicação social nos alerta de novo, para desta vez nos dar conta do sucedido em Coimbra.

Com efeito, elevados quantitativos de precipitação registados, no final do ano de 2000 e princípio de 2001 , levaram a que um pouco por todo o país e nomeadamente em Coimbra (fig. 1), muitas vertentes que se encontravam em situações de equilíbrio precário, acabassem por se movimentar em função da grande

\footnotetext{
* Instituto de Estudos Geográficos, Faculdade de Letras, Universidade de Coimbra.

** Departamento de Engenharia Civil, Polo II, Universidade de Coimbra.
}

quantidade de água que nelas se foi acumulando, a qual provocou uma subida da superfície freática, diminuindo a força resistente e aumentando o peso e a força instabilizadora (L. LEMOS, L. LOURENÇO e C. GONÇALVES, 2001).

Embora essa deslocação seja perfeitamente normal na evolução das vertentes situadas nas nossas condições climáticas, este ano, quer pela quantidade anormal das movimentações registadas, quer, sobretudo, pela quantidade da massa deslocada nalguns desses casos, o início deste ano hidrológico acabou por apresentar contornos de anormalidade, quer pelas longas sequências do número de dias com precipitação, quer pelos valores das quedas pluviométricas (QUADRO I), quer, ainda pela quantidade de movimentações em massa que esta pluviosidade anormal desencadeou. 
70,0

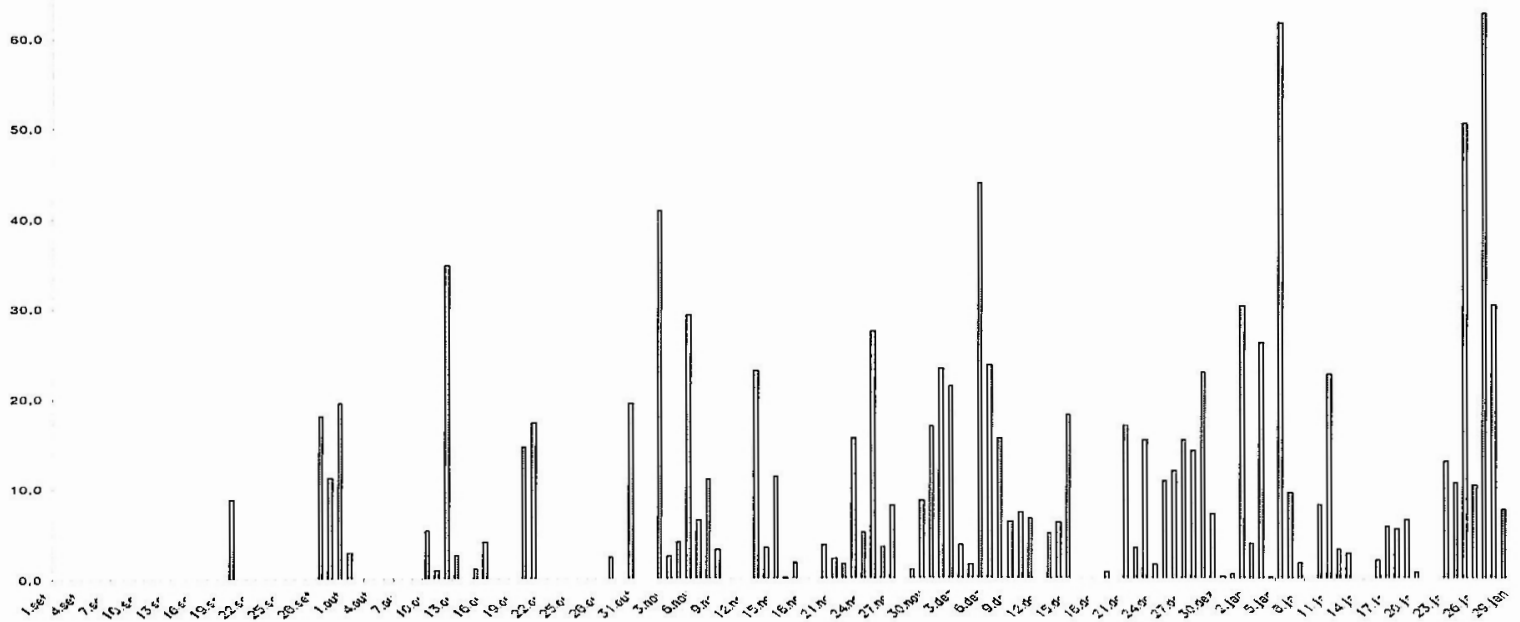

Fig. 1 - Distribuição dos valores diários da pluviosidade registada em Coimbra, no início do ano hidrológico de 2000/2001 (Out-Jan).

Com efeito, os valores da precipitação registada ao longo dos diferentes meses do ano de 2000 afastaramse bastante dos valores normais, quer no que concerne ao número de dias com chuva, quer no que respeita aos respectivos quantitativos. Os meses de Janeiro, Fevereiro, Março, Junho, Agosto, Setembro e Outubro foram deficitários em dias com chuva, enquanto que os meses de Maio, Julhoe, sobretudo, Abril, Novembro e Dezembro foram excedentários, relativamente ao normal, o que sucedeu também em Janeiro do ano seguinte (fig. 2).

Mas, se o número de dias em que choveu foi importante, porque nos dá conta da continuidade ou não da sequência pluviosa, ou seja, da repetição de dias com chuva, mais importante ainda foi a quantidade de água precipitada, a qual, em termos de sequência mensal, se assemelha à anterior. No entanto, há algumas diferenças que interessa assinalar, sobretudo

QUADRO I

Valores normais da precipitação média mensal $(\mathrm{mm})$ e do número de dias com precipitação (nd), registados no Instituto Geofísico da Universidade de Coimbra, nos períodos de 1951/80, 1961/90 e 1971-2000, comparativamente com os observados em 2000 e 2001 (Jan).

\begin{tabular}{|r|c|c|c|c|c|c|c|c|}
\hline \multirow{2}{*}{ Mês } & \multicolumn{4}{|c|}{ nd } & \multicolumn{4}{c|}{$\mathrm{mm}$} \\
\cline { 2 - 9 } & $(51-80)$ & $(61-90)$ & $71-00)$ & $(00-01)$ & $(51-80)$ & $(61-90)$ & $(71-00)$ & $(00-01)$ \\
\hline 2000 Jan & 14 & 16 & & 5 & 145,9 & 137,8 & 120,5 & 10,8 \\
\hline Fev & 15 & 15 & & 5 & 140,0 & 140,3 & 115,4 & 26,5 \\
\hline Mar & 16 & 14 & & 9 & 121,8 & 88,5 & 71,7 & 59,1 \\
\hline Abr & 12 & 14 & & 27 & 77,7 & 90,4 & 90,8 & 198,8 \\
\hline Mai & 12 & 12 & & 16 & 80,6 & 78,6 & 84,6 & 103,7 \\
\hline Jun & 9 & 9 & & 3 & 47,3 & 51,4 & 44,2 & 6,7 \\
\hline Jul & 4 & 5 & & 7 & 12,4 & 13,6 & 15,3 & 24,6 \\
\hline Ago & 6 & 5 & & 3 & 15,5 & 12,9 & 14,7 & 17,0 \\
\hline Set & 9 & 8 & & 3 & 47,6 & 47,7 & 54,6 & 38,0 \\
\hline Out & 13 & 13 & & 12 & 95,3 & 96,4 & 107,8 & 124,8 \\
\hline Nov & 14 & 14 & & 21 & 124,5 & 128,9 & 116,2 & 214,1 \\
\hline Dez & 15 & 14 & & 26 & 129,7 & 129,9 & 139,0 & 319,6 \\
\hline 2001 Jan & 14 & 16 & & 23 & 145,9 & 137,8 & 120,5 & 375,3 \\
\hline
\end{tabular}




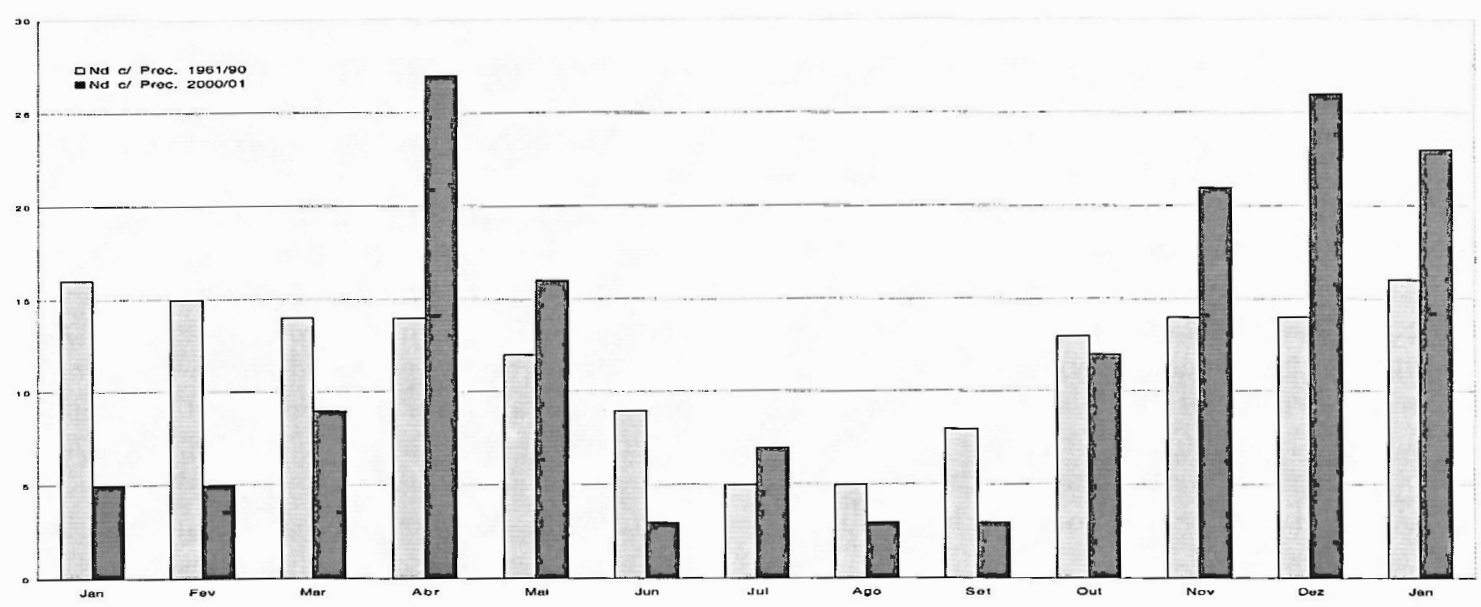

Fig. 2 - Distribuição mensal do número de dias com precipitação observados em Coimbra, no ano de 2000 e 2001(Jan), comparativamente com os valores normais no período de 1961/90.

no início do ano hidrológico 2000/01. Efectivamente, verificou-se que, a partir de Outubro, todos os meses registaram pluviosidade superior ao normal e, no período de Outubro a Janeiro, duplicou-se mesmo esse valor (fig. 3), pelo que o início do ano hidrológico foi completamente anormal, não só pela quantidade de precipitação registada, mas também e sobretudo pela sua sucessão no tempo, quase ininterruptamente ao longo dos quatro meses, só com ligeiros intervalos após o início das chuvas.

\section{A movimentação em massa}

Quando, há pouco mais de meia dúzia de anos, N. GANHO, L. LOURENÇO e F. REBELO (1992, p. 82) alertavam para a importância do conhecimento das "características do suporte físico do sector oriental de Coimbra, nomeadamente a topografia e os declives, nalguns sectores acentuados, a abundância do material de vertente e a grande densidade de drenagem, conjugados com o carácter das precipitações, [que]

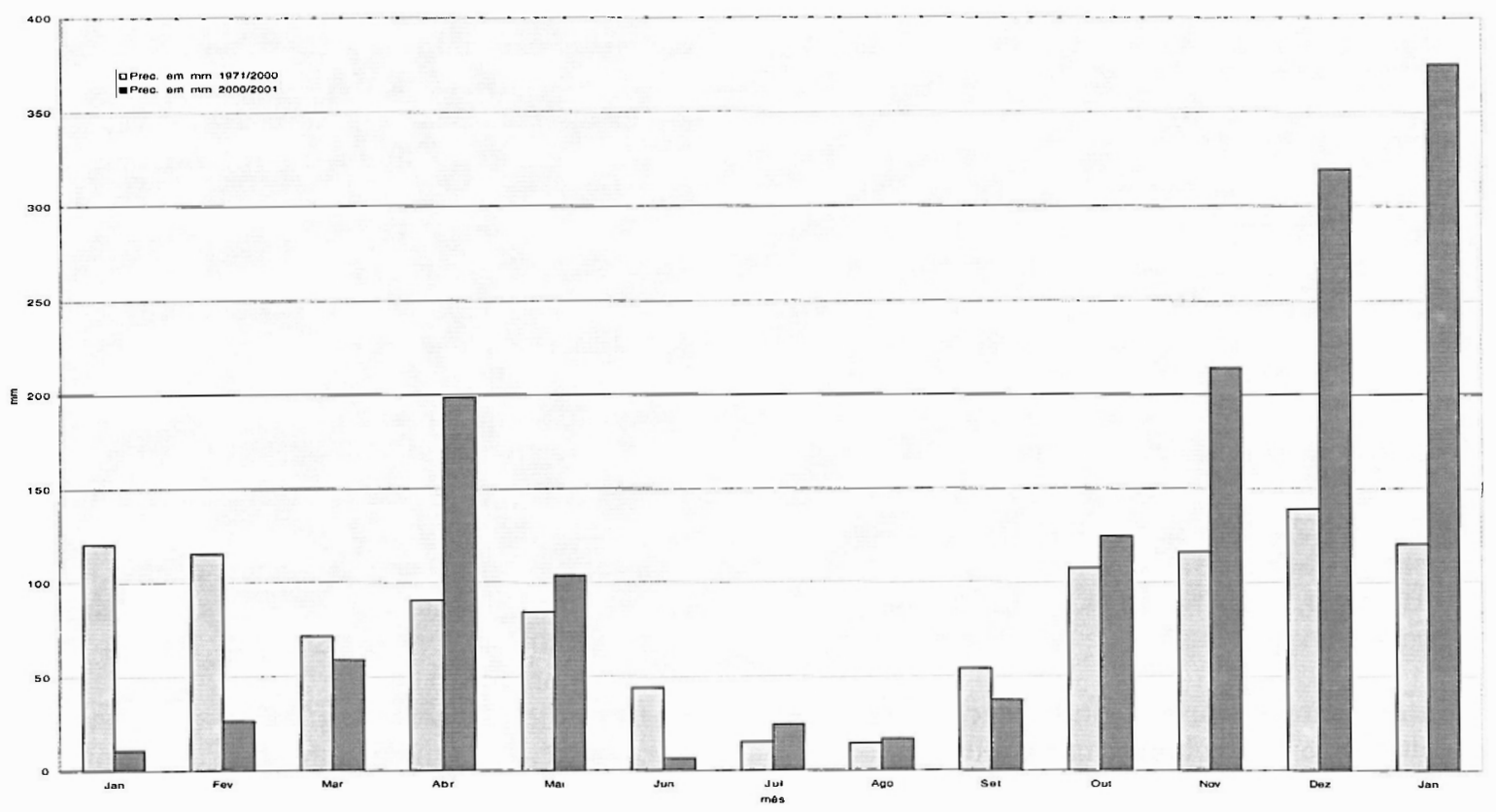

Fig. 3 - Distribuição dos valores da precipitação mensal registada em Coimbra no ano de 2000 e 2001 (Jan), comparativamente com os valores normais nos periodos de 1971/2000. 
são alguns dos aspectos que lhe atribuem uma certa instabilidade natural" estavam bem longe de imaginar que, poucos anos depois, os seus receios viriam a ser confirmados de um modo tão vincado.

Com efeito, consideravam que essa instabilidade natural "não sendo limitativa à ocupação do solo, exigia uma planificação racional das acções humanas, com vista a minorar os efeitos negativos que estas podem gerar na dinâmica natural" e que alguns dos "efeitos que frequentemente se podem observar nesta área, parecem evidenciar uma planificação um tanto descuidada relativamente a alguns aspectos do meio natural" (idem, p. 82), o que, infelizmente, se veio a confirmar muito mais cedo e com maior gravidade do que seria imaginável.

Apesar desta situação ser previsível e tendo-se até apontado como exemplo a Avenida Elíseo de Moura (ibidem, p. 80), não se podia precisar nem o dia nem a hora a que tal evento iria acontecer e, muito menos, as proporções que poderia tomar, na medida em que, para as dimensões destas, concorrem várias ordens de factores, com características e intensidades diferentes e que dependem do modo como interferem uns e outros, pelo que vários cenários poderiam ter sido equacionados, em função de cada uma das circunstâncias ponderadas.

Contudo, alguns movimentos, ocorridos cerca de dois anos e meio antes, indiciavam muito claramente, a instabilidade da vertente, traduzida por um início de deslizamento, felizmente sem consequências graves, mas que, desde logo e para prevenir a sua evolução no futuro próximo, obrigou os moradores da Rua António Jardim, a solicitar um estudo geotécnico (L. LEMOS, 1997) e a construir uma estrutura de suporte correctivo nos logradouros das respectivas moradias (A. MACEDO, 1998).

Decorridos sensivelmente dois anos após a execução dessa estrutura, quantitativos anormais de precipitação, registados sobretudo em Novembro e Dezembro (figs. 1 e 3), levaram a que, no início do Inverno, ocorresse o deslizamento que atirou Coimbra para a ribalta, em termos de meios de comunicação social, não só com honras de abertura e de directos em telejornais, mas também como notícia de primeira página dos principais diários, tanto mais que a evolução da situção criada pelo deslizamento ameaçou complicarse nos dias seguintes, que continuavam a registar precipitações elevadas (fig. 1).

Mas, afinal, quais foram as causas? O que é que terá provocado, originado este deslizamento?

\section{Antecedentes históricos -intervenção antrópica e alteração da evolução natural da vertente}

Ora, para se encontrar resposta às questões antes colocadas, ou seja, para se encontrar uma explicação que, de modo lógico e sequencial, permita justificar cabalmente o sucedido é necessário, quanto a nós, remontar no tempo e, talvez, até um pouco mais do que aquiloque, aparentemente, poderá parecer necessário.

Assim sendo, o início do processo deverá procurarse nas alterações que o homem, de maneira consciente e deliberada, ou talvez não, pouco a pouco foi introduzindo na dinâmica natural da vertente. Deixando de lado, porque se perde na memória do tempo, as primeiras transformações por ele efectuadas, com o objectivo de nela fazer agricultura, e as alterações que, posterior e paulatinamente, lhe foi introduzindo com esse mesmo objectivo, não será necessário recuar muito no tempo - serão sufucientes menos de trinta anos - para confirmarmos a utilização essencialmente agrícola da vertente em questão, onde, mesmo hoje, ainda podemos observar "tabuleiros" e algumas oliveiras que testemunham essa anterior ocupação.

Concomitantemente com essa actividade agrícola, estava implícita a necessidade de rega dos campos, a qual obrigou o homem a escavar galerias subhorizontais, denominadas minas, para captar as águas da circulação subterrânea, relativamente abundantes. Com base em relatos dos moradores mais antigos, profundos conhecedores da vertente antes das recentes alterações, foi possível localizar duas minas no local do deslizamento e uma terceira imediatamente a NE do aterro, das quais, na actualidade, apenas esta última se conserva em actividade. Estas minas, embora feitas para rega, ao drenarem as águas subterrâneas, contribuíam para a estabilização das encostas.

À parte de outras causas de ordem geral, uma das que, a nível local, mais contribuiu para o rápido declínio da actividade agrícola e consequente abandono dos campos cultivados na vertente, foi a abertura da Avenida Elísio de Moura e o forte urbanismo que esta desencadeou em toda a área envolvente.

A pressão urbanística entretanto estimulada, levou a que a no início da década de 80 , portanto, há cerca de 20 anos, se tivessem iniciado as escavações para construir as fundações e os andares inferiores dos mais altos edifícios actualmente existentes nessa avenida e ao transporte, durante meses sucessivos, dos materiais resultantes do desaterro provocado pelas escavações para o topo da vertente, onde foram despejados, ao contrário do que recomendam as mais elementares normas de segurança geomorfológica, criando uma plataforma artificial onde, anos mais tarde, viriam a ser construídos os logradouros das vivendas ora afectadas.

Com efeito, foram edificadas as vivendas ora afectadas na Rua António Jardime, quase de imediato, os primeiros prédios da Av. Elísio de Moura. O último, que agora foi danificado, terá sido iniciado por volta de 1986 (fot. 1). A construção destes prédios, 


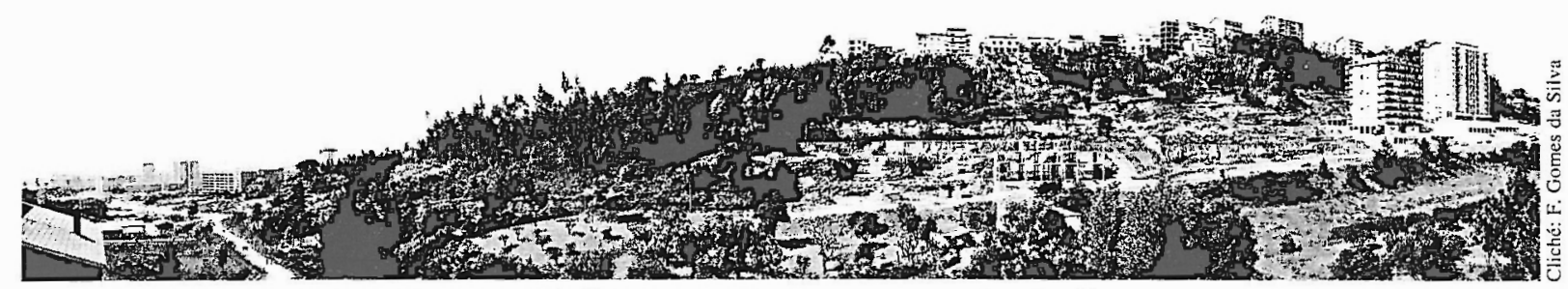

Fot. 1 - Aspecto geral da vertente onde ocorreu o deslizamento, observando-se no topo as vivendas, já construídas, e os respectivos logradouros, assentes nos aterros efectuados com os materiais retirados da base da vertente, na qual são visíveis as cicatrizes deixadas pelas escavaçóes efectuadas para implantação dos prédios recentemente construídos na Ava . Elísio de Moura. O edifício que se encontrava no início da sua construção corresponde ao prédio que foi agora mais afectado.

na Av. Elísio de Moura, obrigou à criação de uma plataforma, tendo-se procedido a escavações nos grés do Triásico, com desmonte a fogo.

Grande parte dos materiais resultantes destas escavações foram transportados para a área das vivendas situadas na Rua António Jardim e ali depositados sem qualquer compactação. Por esse motivo, estes depósitos de aterro encontravam-se soltos e possuíam um elevado índice de vazios. Por conseguinte, apresentavam uma elevada capacidade de absorção de água e, quando saturados, tinham, no estado crítico, uma baixa resistência não drenada ao corte.

A simples deposição dessas terras, transportadas da base para o topo da vertente, veio aumentar significativamente os riscos de instabilidade dessa vertente, na medida em que, por um lado, não só se carregou no topo, mas também se descarregou a base do talude, aumentando assim o momento instabilizador e, por outra parte, não se acautelou a construção de um verdadeiro aterro. Com efeito, não se criaram condições que permitissem manter o escoamento existente antes da deposição do aterro, quer das águas provenientes das minas, quer das águas provenientes das infiltrações no aterro e concentradas na antiga linha de água, agora fossilizada, mas também não se procedeu à devida consolidação e compactação desse aterro.

Quanto ao escoamento subterrâneo, que jorrava através das minas, passou a ficar obstruído porque as saídas dessas minas foram tamponadas com materiais do aterro. A água, que passou a acumular-se no interior dessas minas, poderá ter contribuído para o provável abatimento do tecto de uma delas, deduzido pela existência de um degrau na vertente e que parece corresponder ao seu anterior traçado, como, sobretudo, por ter deixado de ter a anterior função drenante e estabilizante.

Noque respeita ao escoamento subaéreo, superficial, transformou-se em parte, pela deposição do aterro, em subsuperficial, uma vez que a água da chuva se passou a infiltrar através dos materiais do aterro e, muito provavelmente, continuou a escoar-se sobre a antiga superfície topográfica, agora fossilizada, concentrando-se no local onde se veio a verificar o deslizamento, por coincidir com as cabeceiras de uma linha de água ainda incipiente e, por esse motivo, corresponder à maior espessura dos materiais depositados artificialmente.

Deste modo, além de se dever ter assegurado a drenagem das águas pluviais, teria sido também fundamental consolidar o aterro para travar o seu gradual deslocamento para a base da vertente, tendo em consideração o elevado declive da mesma. Essa consolidação implicava a construção de estruturas de suporte e a compactação dos materiais despejados, o que, além de reduzir a infiltração das águas pluviais, dificultaria a movimentação do depósito, pressupostos que não foram executados.

Nestas circunstâncias, tendo em conta que não se assegurou a conveniente drenagem das águas pluviais, nem se procedeu à compactação dos materiais depositados, nem sequer se estabilizou a vertente com nenhuma estrutura de suporte das terras, mais do que num verdadeiro aterro, como hoje tecnicamente os entendemos, deverá falar-se antes, talvez até com mais propriedade, em vazadouro de terras, porque não foram respeitadas as normas de segurança apropriadas nestas circunstâncias.

Ora, porque o talude não foi devidamente estabilizado na altura da construção do "aterro", procuraram-se, a posteriori, soluções alternativas que reduzissem a movimentação dos materiais ao longo da vertente. Com esse objectivo, começaram por proceder à plantação de eucaliptos, que, como era de esperar se desenvolveram muito rapidamente.

Decorrida mais de uma dezena de anos, os eucaliptos atingiram um tal desenvolvimento vertical que, na nossa opinião, passaram a ter um efeito contrário ao inicialmente previsto, na medida em que as suas raízes não conseguiram alcançar a antiga superfície topográfica e, por conseguinte, pouco contribuíram para estabilizar o depósito de vertente.

Pelo contrário, poderão mesmo ter tido um efeito negativo, sobretudo em situações de vento forte, uma vez que, devido à sua elevada altura, alguns exemplares possuíam mais de vinte metros, transmitiam uma movimentação à camada superficial do depósito que, além de forçar o deslocamento dos materiais 
circundantes, permitia a abertura de fissuras nesses materiais, ao longo das quais a água da chuva se infiltrava com mais facilidade e, deste modo, acrescia a instabilidade da vertente.

Contudo, embora todos estes factores tenham de ser considerados, pois só através da sua análise conjunta será possível encontrar cabal explicação para os factos ocorridos, não deixa de ser verdade que, nestas circunstâncias, os grandes responsáveis directos pelo desencadear do fenómeno foram, sobretudo, os elevados quantitativos de precipitação verificados antes do deslizamento (fig. 4).

Além da pluviosidade verificada imediatamente antes da ocorrência, também a precipitação antecedente deve ser tida em linha de conta (fig. 1), na medida em que esta foi a principal responsável pelo aumento das reservas de água subterrâneas, as quais terão sido responsáveis pela diminuição da resistência verificada na base do depósito, devido à subida da superfície freática, e que levou ao desencadear do deslizamento. Contudo, nesta análise, não podemos nem devemos esquecer que, anteriormente a este deslizamento, já tinham sido emitidos alguns avisos.

Comefeito, no Inverno de 1995, foram observados sinais de instabilidade na vertente, tendo sido feita uma intervenção de estabilização, a qual consistiu na construção de um muro de gravidade de betão armado, com uma altura de 4,5 metros, que supostamente se encontrava fundado nos grés/arenitos.
Depois disso, no Inverno de 1997, foram verificados novos sinais de instabilização, tendo aparecido fissuras nas vivendas e fendas nos respectivos logradouros. Para o final do Inverno, verificou-se o início da formação do processo de deslizamento, tendo a superfície de rotura aflorado no meio do logradouro, na qual se pôde observar, através do degrau correspondente à cicatriz de arranque, um deslocamento de cerca de 80 centímetros. No entanto, não foi possível detectar qualquer indício de rotura na zona de compressão, ou seja, na base do talude, por nela não ser visível superfície de rotura e, por isso, não ter sido possível observá-la.

No entanto, para se poder impedir que os materiais deslocados continuassem a deslizar, começou por se proceder à identificação do problema (L. LEMOS, 1997). Depois de se ter efectuado o estudo topográfico, através de cartas antigas, anteriores à colocação do aterro, e de cartas recentes, posteriores à deposição do mesmo, de se terem realizado prospecções mecânicas, com identificação das amostras e ensaios de penetração dinâmica SPT (Standard Penetration Tests), e de se terem efectuado cálculos de estabilidade, através do método de equilíbrio limite de Sarma, decidiu-se executar estacas de $80 \mathrm{~cm}$ de diâmetro, espaçadas de 1,5 metros, devidamente encastradas na base e solidarizadas no topo, através de uma viga de 1,0 por 1,5 metros, a qual, por sua vez, foi ancorada (fot. 2). Os logradouros foram impermeabilizados

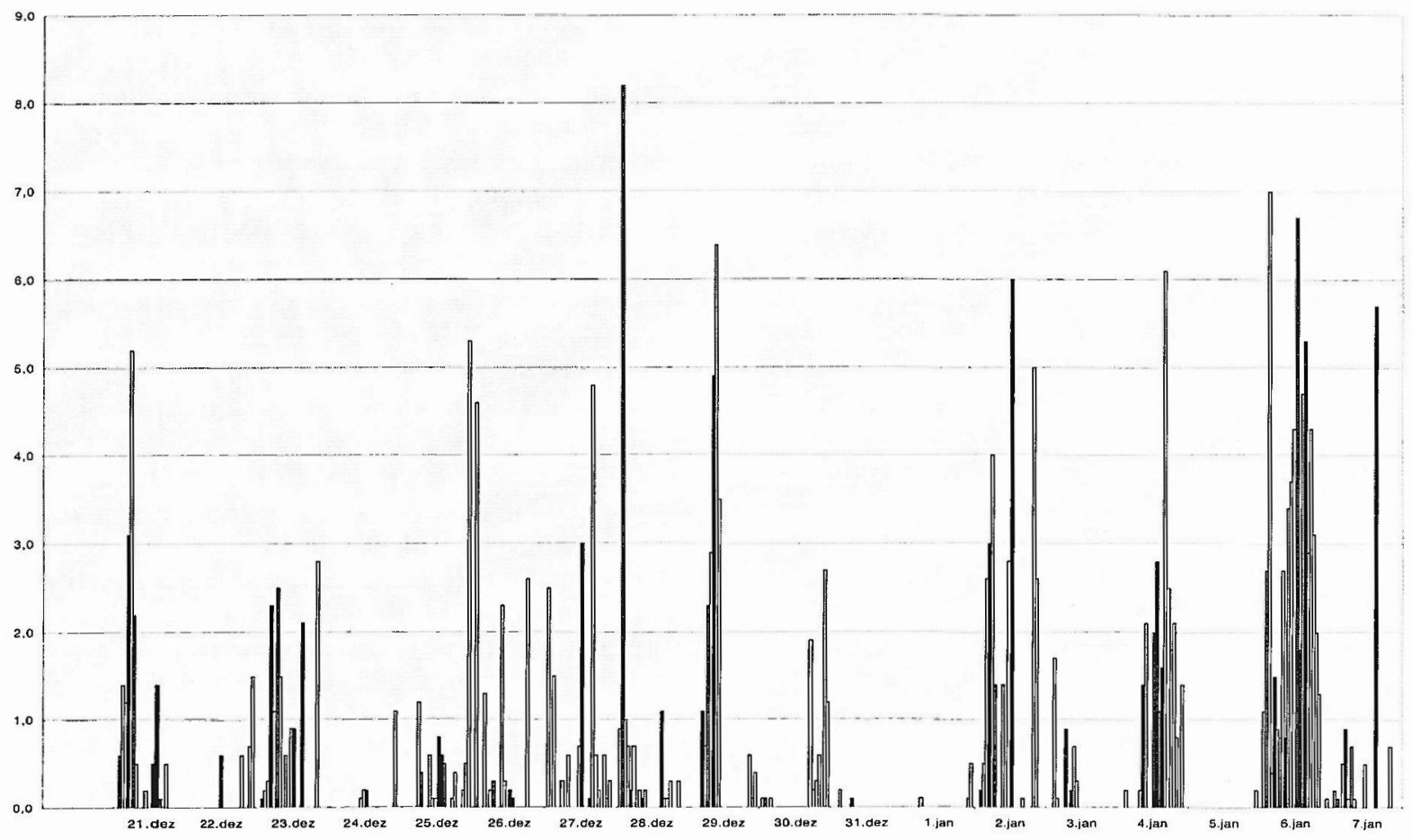

Fig. 4 - Valores horários da precipitação registada em Coimbra nos dias que antecederam e se seguiram ao deslizamento. 


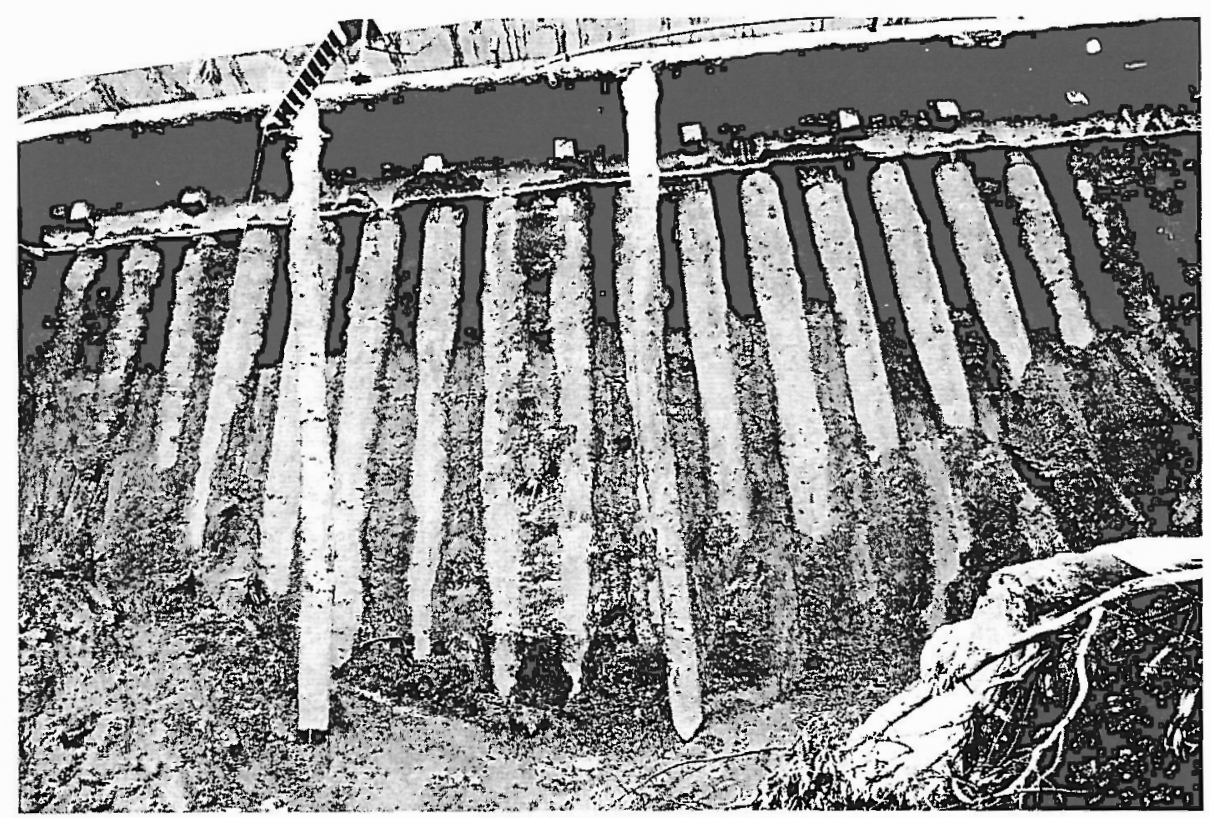

Fot. 2 - Vista geral da estacaria de suporte, após o deslizamento.

com uma laje térrea de betão pobre e todas as águas superficiais foram colectadas e devidamente canalizadas.

Apesar desta intervenção, em 27 de Dezembro de 2000 , por volta das 21 horas, verificou-se um escorregamento que mobilizou uma superfície de rotura localizada imediatamente à frente das estacas. Contudo, o conjunto - estacas, viga e ancoragens - funcionou correctamente, tendo evitado que a rotura se tivesse efectuado pela superfície de deslizamento mais desfavorável, correspondente à observada em 1997, e, por conseguinte, impediu-se também a destruição das vivendase, reduziu-se significativamente o volume de terras deslocado para cima do prédio da Avenida Elísio de Moura.

Com efeito, se o material contido a montante das estacas se tivesse deslocado, este iria provocar, muito provavelmente, o desmoronamento total ou parcial do prédio da Avenida Elísio de Moura. Deste modo, além das vantagens já mencionadas, a construção da estacaria foi, ainda, importante porque evitou a perda de vidas humanas, tanto no prédio como nas vivendas.

\section{Análise da geologia e da estabilidade da vertente no local do deslizamento}

O substrato é constituído por formações de grés/ /arenito do Triásico, com pendores de 20 a $25^{\circ}$ para $\mathrm{SW}$, apresentando-se, por vezes, fracturadas, facilitando, por isso, a percolação. Os grés possuem uma tonalidade castanho-avermelhada e, por vezes, apresentam-se conglomeráticos, com intercalações silto-argilosas ou areno-argilosas, de alguma plasticidade. Sobre o grés encontra-se um depósito de vertente, coberto por um solo residual, de características areno-silto-argilosas (SC-SM), contendo, por vezes, alguns seixos.

Esta camada apresentava uma espessura variável entre 3 e 4,5 metros, sendo preenchida, no topo, por uma camada vegetal com cerca de 1,0 metro. Os ensaios SPT feitos na camada de grés mostraram penetrações entre 9 e $12 \mathrm{~cm}$ para as 60 pancadas. Para o depósito de vertente e no solo residual obtiveram-se, em média, 25 pancadas, na segunda fase de penetração.

No aterro, sobre o qual se implantaram os logradouros das vivendas da Rua António Jardim, foram efectuadas três sondagens com sonda de percussão mecânica, no diâmetro de $150 \mathrm{~mm}$, que atingiram profundidades variáveis, compreendidas entre $17,58 \mathrm{~m}$ e $18,24 \mathrm{~m}$. A partir das amostras recolhidas durante a furação, fez-se a classificação litológica, macroscópica, dos terrenos atravessados e determinou-se a espessura de cada uma das diferentes camadas. Efectuaram-se vinte e cinco ensaios de penetração dinâmica SPT que, como é corrente, foram executados em duas fases: a fase inicial, com a penetração de $15 \mathrm{~cm}$ (fig. 5), e a fase definitiva, com a penetração de $30 \mathrm{~cm}$ (fig. 6). 


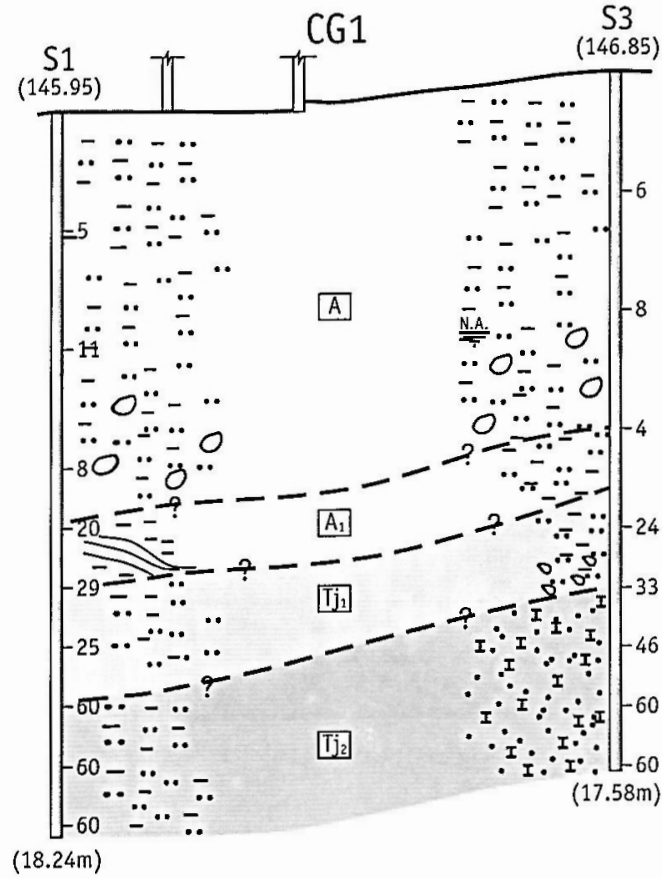

Fig. 5 - Corte geológico resumo entre as sondagens S1 e S3.

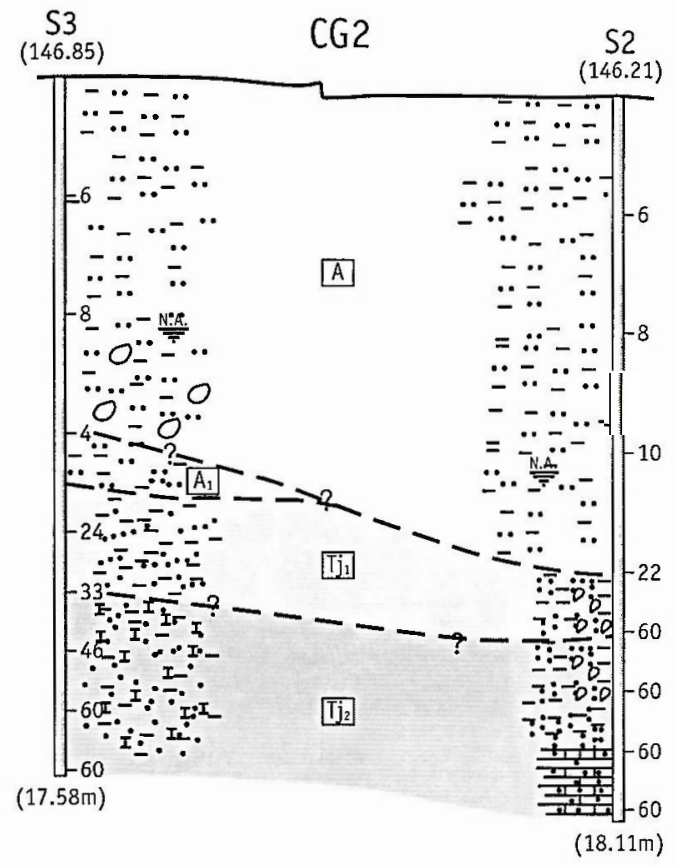

Fig. 6 - Corte geológico resumo entre as sondagens S2 e S3.
À superfície, a área abrangida pelo reconhecimento está ocupada por materiais de aterro colocados no local, os quais constituem uma plataforma sobranceira à encosta, com declive da ordem dos $45^{\circ} \mathrm{e}$ que se desenvolve ao longo das traseiras das moradias existentes. De acordo com os resultados obtidos através das sondagens efectuadas no local, os aterros ali existentes apresentam profundidades variáveis entre 9,0 e $12,0 \mathrm{~m}$. São constituídos por materiais predominantemente argilo-siltosos, aos quais, de acordo com os resultados obtidos nos ensaios SPT $(5 \leq \mathrm{N} \leq 11)$, é permitido atribuir deficientes características de compactação.

Em duas das sondagens (S1 e S3) reconheceu-se, na base dos aterros, uma camada de argila siltosa e/ou arenosa, com cerca de 1,5 $\mathrm{m}$ de espessura, algo meteorizada, onde se recolheram fragmentos de madeira, porventura raízes, que poderá corresponder $\grave{a ̀ ~ a n t i g a ~ c a m a d a ~ v e g e t a l . ~}$

O substratolocal é integrado por formações gresosas do Triásico que, até às profundidades atingidas, se revelaram constituídas por uma sucessão relativamente monótona de argilas areno-siltosas e areias argilosas de tons avermelhados, apresentando em alguns níveis elementos grosseiros incorporados (seixo fino a médio). Os horizontes superiores do substrato, com uma espessura de cerca de 3 metros, apresentavam-se relativamente descomprimidos ou alterados $(22 \leq \mathrm{N} \leq 29)$, tendo-se registado na base das sondagens, nos grés, a ocorrência de estratos com resistência elevada (penetrações da ordem de $10 \mathrm{~cm}$ para as 60 pancadas).

No decorrer da furação detectou-se o aparecimento de água subterrânea nas sondagens S2 e S3, às profundidades, respectivamente, de $10,9 \mathrm{~m}$ e $7,6 \mathrm{~m}$. Os trabalhos de sondagem foram realizados na última semana do mês de Junho de 1998.

As prospecções vieram confirmar os dados obtidos através da análise das cartas topográficas, ou seja, a existência de um aterro não compactado, com uma espessura situada entre 9 e 12 metros, nos logradouros das vivendas. $\mathrm{O}$ aterro estendia-se depois por uma extensão de cerca de 20 metros com declives da ordem de $45^{\circ}$, no qual, se encontrava uma plantação de eucaliptos de grande porte.

Num corte efectuado na parte mais desfavorável do terreno situado na área das vivendas na Rua António Jardim (fig. 7) pudemos identificar, do topo para a base, os três seguintes tipos de materiais: a) depósito resultante do aterro; $b$ ) depósito de vertente; c) grés.

Para a análise de estabilidade foram adoptados os seguintes valores: 


\begin{tabular}{|l|l|l|l|}
\hline & depósito de aterro & depósito de vertente & \multicolumn{1}{c|}{ grés } \\
\hline peso volúmico & $\gamma=18 \mathrm{kN} / \mathrm{m}^{3}$ & $\gamma=20 \mathrm{kN} / \mathrm{m}^{3}$ & $\gamma=22 \mathrm{kN} / \mathrm{m}^{3}$ \\
\hline $\begin{array}{l}\text { ângulo de resistência } \\
\text { ao corte }\end{array}$ & $\phi^{\prime}=30^{\circ}$ & $\phi^{\prime}=32 \mathrm{a} 35^{\circ}$ & $\phi^{\prime}=40^{\circ}$ \\
\hline $\begin{array}{l}\text { coesão aparente ou } \\
\text { intersecção na origem }\end{array}$ & $c^{\prime}=5 \mathrm{kN} / \mathrm{m}^{2}$ & $c^{\prime}=10 \mathrm{a} 20 \mathrm{kN} / \mathrm{m}^{2}$ & $\mathrm{c}^{\prime}=200 \mathrm{kN} / \mathrm{m}^{2}$ \\
\hline $\begin{array}{l}\text { razão da pressão da } \\
\text { água nos poros (a } \\
\text { razão entre a pressão } \\
\text { da água num ponto e } \\
\text { a tensão total nesse } \\
\text { ponto) }\end{array}$ & $\mathrm{r}_{\mathrm{u}}=0,2$ & $\mathrm{r}_{\mathrm{u}}=0,2$ & $\mathrm{r}_{\mathrm{u}}=0,2$ \\
\hline
\end{tabular}

O resultado da análise de estabilidade efectuada com o método de Sarma, utilizando superfícies de rotura circulares, na qual se representou a superfície de rotura crítica, permitiu obter um factor de segurança de 1,0 (fig. 8). A superfície de rotura aflorou na zona dos logradouros das vivendas, sendo aproximadamente coincidente com as fendas observadas, devido ao escorregamento verificado no local.

Convém salientar que este factor de segurança foi obtido para um valor de $r$ igual a 0,2 , ou seja, para uma posição da superfície freática correspondente a 0,4 da altura de terras acima da superfície de rotura. Se a superfície freática fosse coincidente com a superfície do terreno então o valor de $r_{u}$ tomaria o valor de 0,5 , para um valor do peso volúmico do terreno de $20 \mathrm{kN} / \mathrm{m}^{3}$. Assim, para uma intensidade de chuvas elevada, que fizesse subir o nível de água no terreno, implicaria um valor de $r_{u}$ superiore, consequentemente, um factor de segurança inferior à unidade.

\section{Obra correctiva realizada em 1998}

As obras correctivas, consideradas em 1998 para estabilização da encosta, podem agrupar-se em torno de quatro hipóteses principais (fig. 9):

a) Aumento da carga estabilizante na base do talude, através da execução de um muro de suporte, e aumento da altura das terras na base do talude, o que obrigaria à intervenção em terrenos de difícil acesso, não pertencentes aos proprietários das vivendas;

b) Execução de drenos sub-horizontais e profundos, que baixassem a superfície freática permanentemente, ou seja, que repusessem a função drenante das minas, com dificuldades de intervenção idênticas às referidas na alínea anterior;

c) Diminuição da carga no topo do talude, através da extracção de terras no topo do talude, tendo como consequência a inutilização dos logradouros e das garagens;

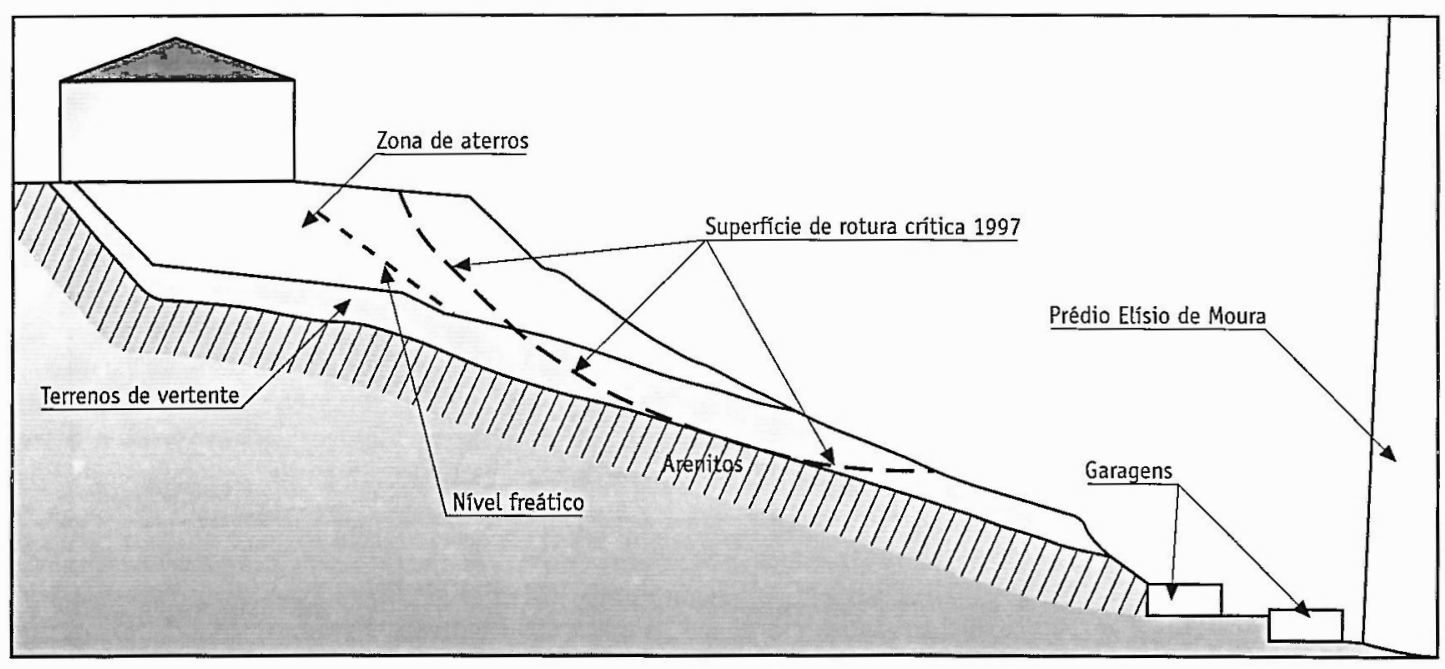

Fig. 7 - Corte efectuado na parte mais desfavorável do terreno situado na área das vivendas na Rua António Jardim 


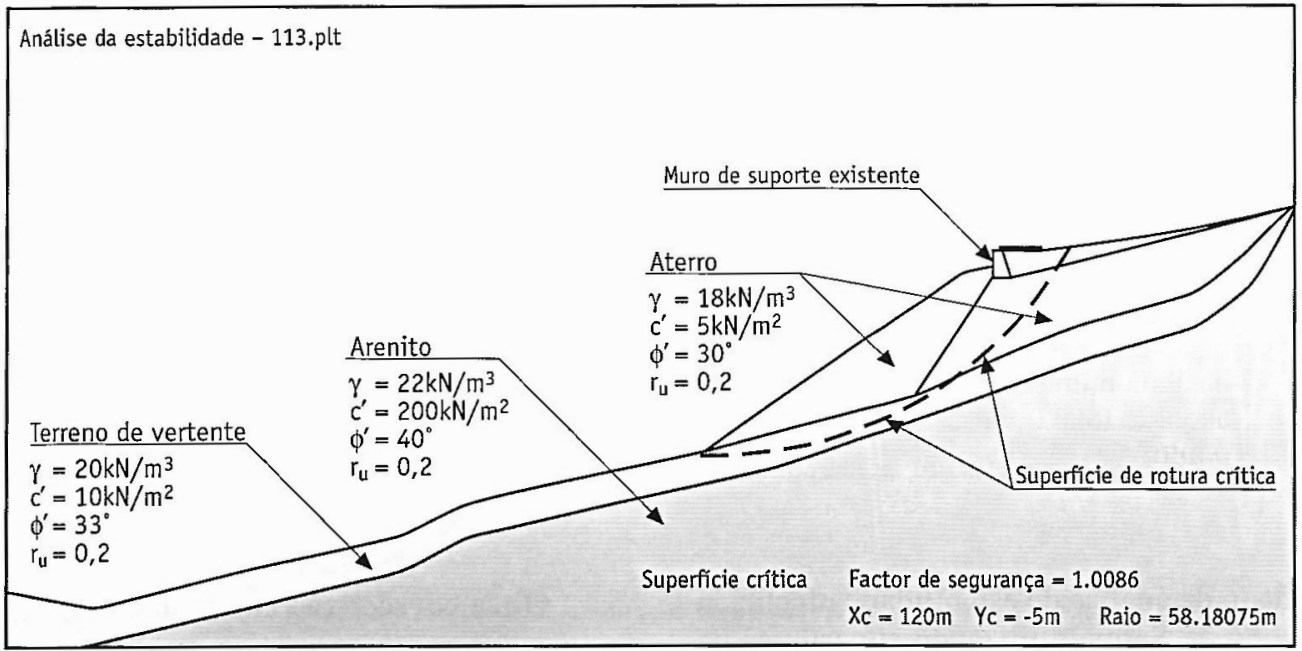

Fig. 8 - Representação da superfície de rotura crítica.

d) Aumento da resistência ao corte, através da execução de uma cortina de estacas que atravessassem a superfície de rotura. Esta solução é mais eficiente na zona de corte simples, ou seja, a meio do talude, com dificuldades de execução provenientes de maus acessos.

Contudo, estando a possibilidade de intervenção limitada à zona dos terrenos pertencentes aos proprietários das vivendas, e ponderadas as soluções referidas acima, foi decidido implementar, na crista do talude, a seguinte solução: execução de uma cortina de estacas, com $80 \mathrm{~cm}$ de diâmetro, afastadas de 1,5 metros, encastradas no grés e solidarizadas no topo através de uma viga com 1 metro de largura e 1,5 metros de altura, ancorada a $1 \mathrm{~m}$ do topo por meio de ancoragens de $600 \mathrm{kN}$ afastadas de 3,0m (fig. 10).

Esta solução apresentou as seguintes vantagens:

a) Implementou, de forma simultânea, as medidas referidas nas anteriores alíneas $c$ ) e $d$ ), pois, as estacas cortaram a superfície de rotura e devido à sua grande rigidez diminuiram a acção de carga das terras no tardoz das estacas.

b) Os intervalos entre as estacas continuam a permitir a drenagem das águas provenientes da parte detrás das estacas.

c) Os moradores puderam continuar a utilizar os logradouros e o passadiço de acesso às garagens.

\section{- $O$ deslizamento de 27 de Dezembro de 2000}

Em 27 Dezembro de 2000 verificou-se, por volta das 21 horas, um escorregamento que envolveu todo o material de aterro situado à frente das estacas (fig. 11), de acordo com a reconstituição da provável superfície de rotura (fig. 12) bem comoda representação em corte, da zona mais profunda do deslizamento, após o escorregamento de terras (fig. 13).

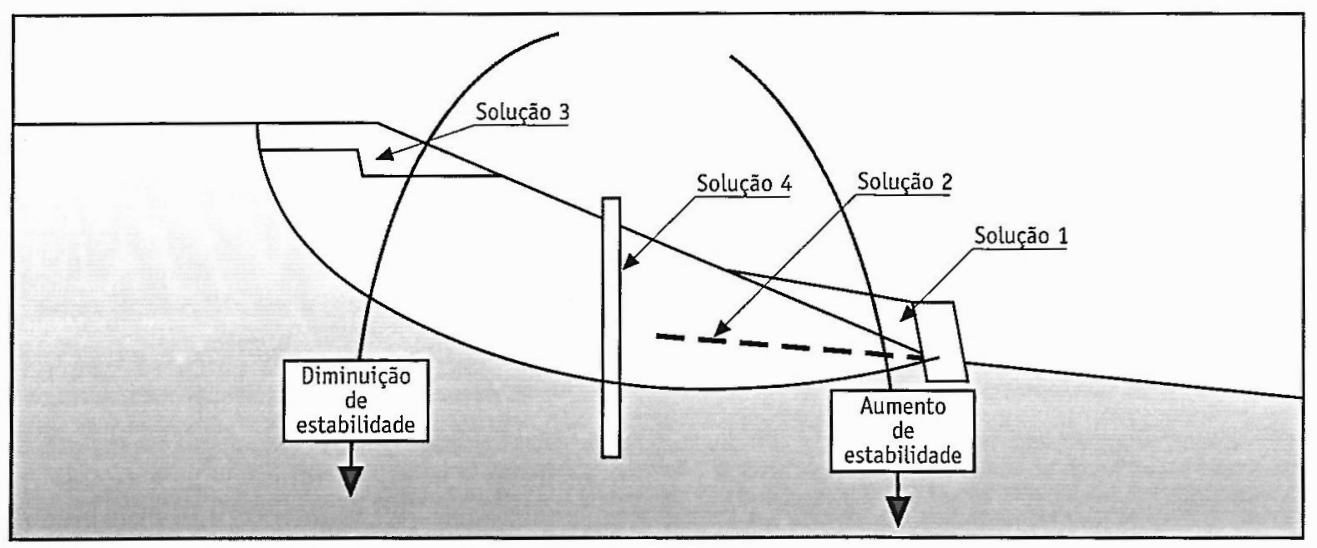

Fig. 9 - Obras correctivas, consideradas em 1998, para estabilização da encosta. 


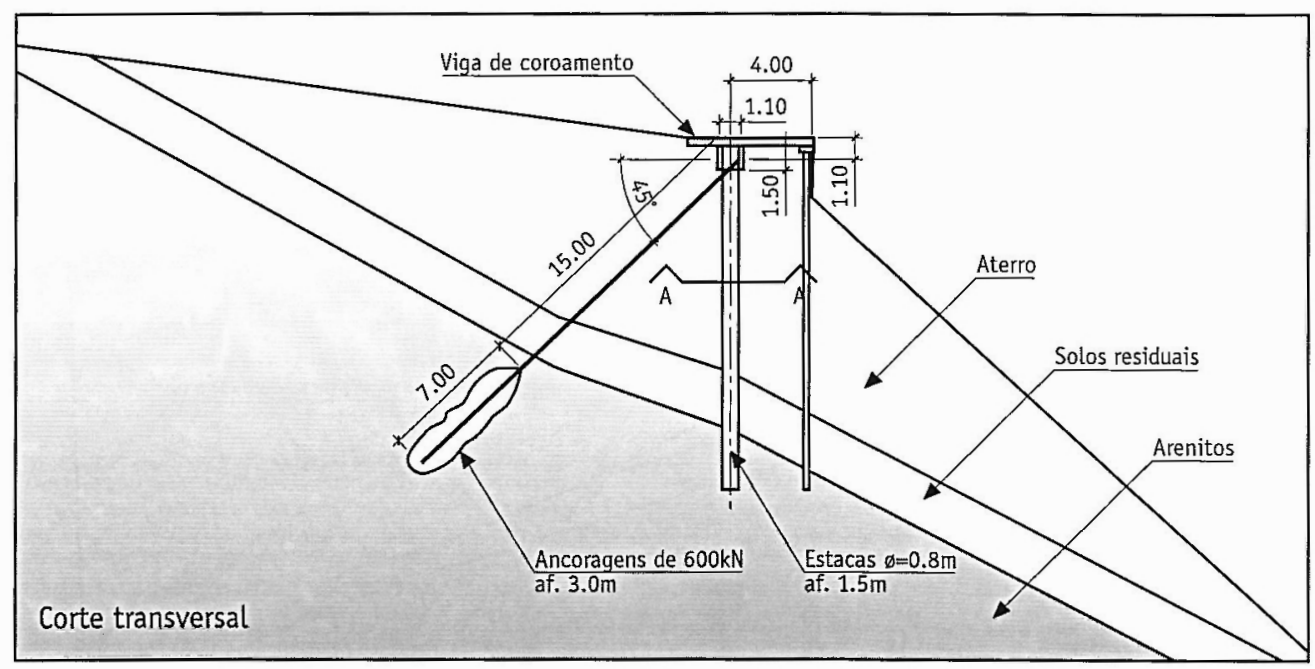

Fig. 10 - Solução implementada para estabilização da encosta.

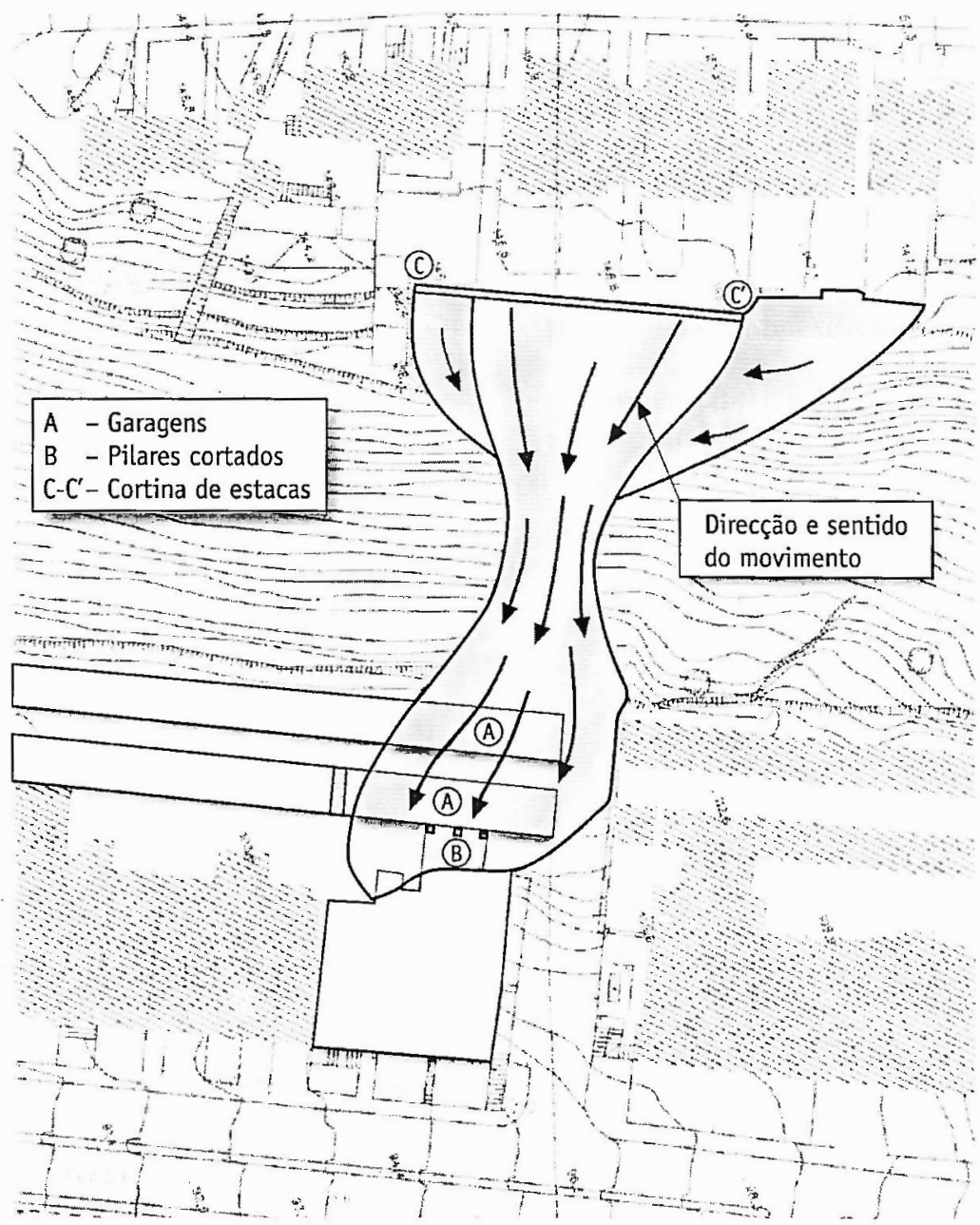

Fig. 11-Vista do desenvolvimento do deslizamento, em planta. 


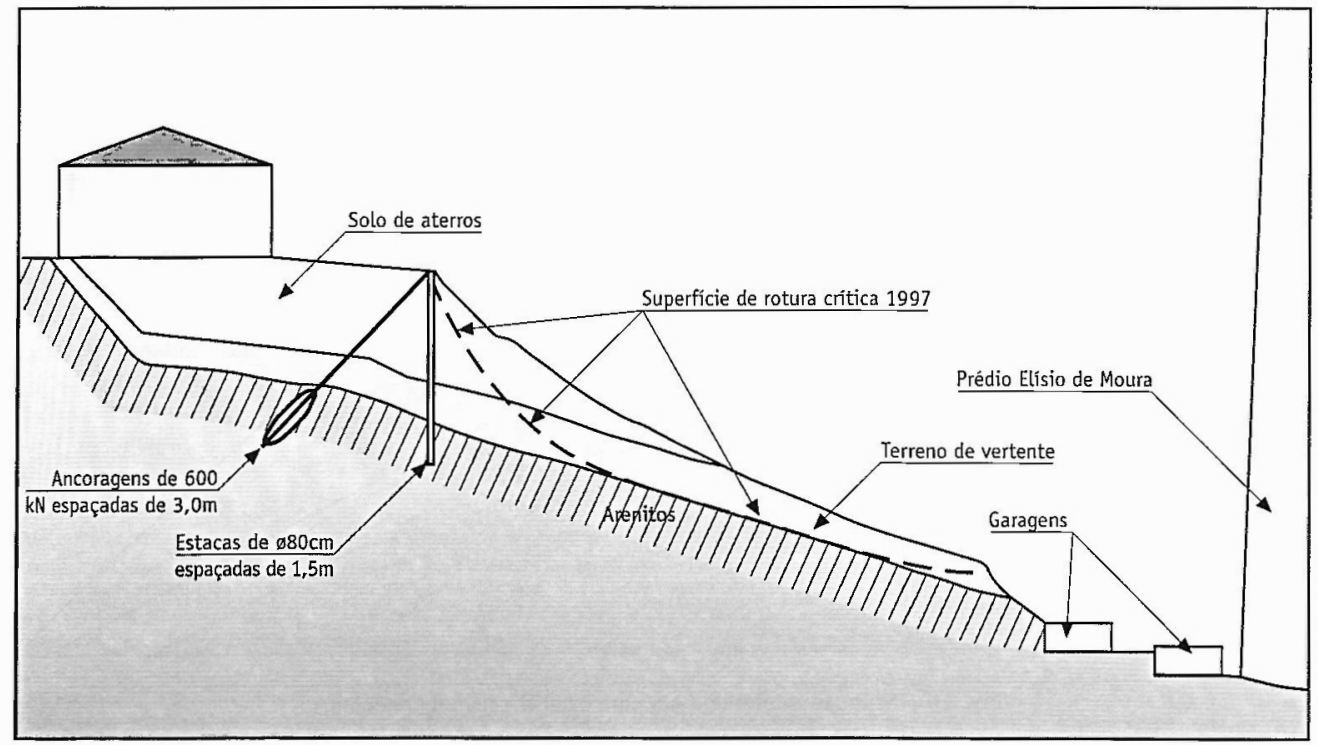

Fig. 12 - Corte com a indicação da provável superfície de rotura.

O volume de terras envolvido no deslizamento foi da ordem dos $4000 \mathrm{~m}^{3}$.

As chuvas intensas e contínuas, verificadas durante os meses de Novembro e Dezembro (fig. 1), conduziram à saturação dos materiais de aterro e a uma subida da superfície freática nos solos que, como consequência, provocou um aumento das pressões intersticiais e um decréscimo das tensões efectivas. Assim, a resistência aocorte diminuiu, mobilizando uma superfície de rotura à frente das estacas.

A superfície de rotura surgida no Inverno de 1997/8, e para os parâmetros de resistência ao corte adoptados, possuía um factor de segurança global unitário para um valor de ru de 0,2. Devido ao Inverno de 2000 ser muito mais chuvoso do que o habitual, os valores de $r$ observados foram superiores, pelo que foi mobilizada uma outra superfície, mais estável do que a crítica verificada em 1997.

No sentido de perceber o mecanismo envolvido no escorregamento apresentam-se algumas descrições feitas pelos moradores da Rua António Jardim:

a) Algum tempo antes do escorregamento, os moradores começaram a ouvir estalos, tendo-se deslocado aos logradouros para se inteirarem do que se estava a passar;

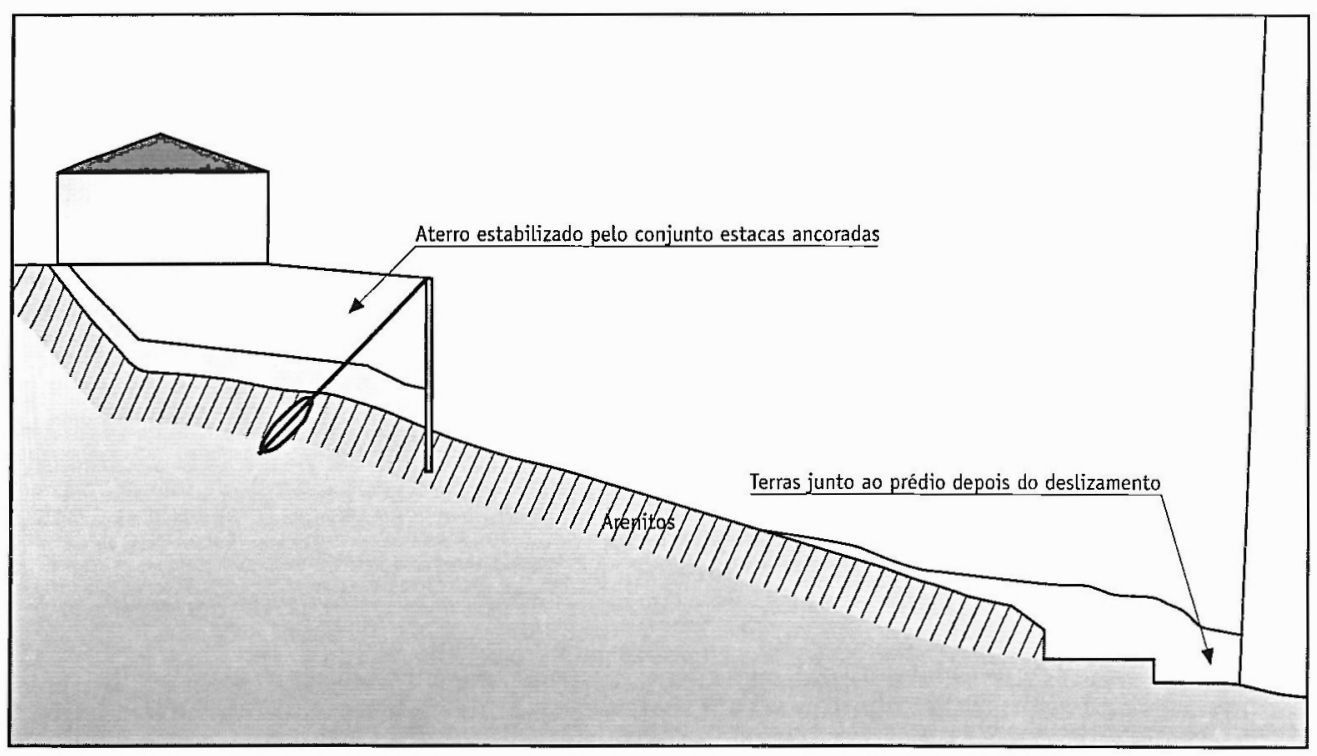

Fig. 13 - Vista em corte da zona mais profunda do deslizamento, após o escorregamento de terras. 
b) Verificaram que existia uma fenda transversal, paralela ao passadiço de acesso às garagens, tendo observado um desnível da ordem de 1 metro. Esta fenda, com o degrau de aproximadamente de 1 metro, situava-se na vertical do passadiço e indica ser o limite superior da superfície de deslizamento;

c) Subitamente, verificaram que os eucaliptos começavam a movimentar-se e ouviram um estrondo violento. Nessa altura todos correram em direcção à Rua António Jardim, ouvindo, seguidamente e durante um longo período de tempo, um barulho idêntico ao de água a correr. Por ser de noite e não existir iluminação no local, não foi possível ver a água, mas apenas ouvir o ruído que produzia.

A massa de terra deslizante (fot. 3 ), deslocou-se a uma velocidade elevada, vindo embater violentamente contra um dos prédios situado na Av. Elísio de Moura, destruindo, na passagem, todas as garagens que se lhe depararam pelo caminho e, por fim, cortou os três pilares existentes num avançado do prédio (fot. 4).

O escorregamento, pela observação da topografia do talude após o deslizamento e pelas descrições dos moradores, pode ser caracterizado pelos seguintes aspectos relevantes:

a) Toda a massa deslizante se deslocou para a base do talude, embatendo com violência contra o prédio (fig 13);

b) A velocidade de deslizamento foi elevada, pois tudo aconteceu em poucos minutos, segundo o testemunho dos moradores; c) Os materiais do aterro fluidificaram após a rotura. Os moradores ouviram, durante algum tempo, "água a correr".

Devido à fragilidade do terreno constituinte da vertente (diferença significativa entre a resistência de pico e residual) e à elevada sensibilidade não drenada do material de aterro (resistência não drenada do solo intacto superior à do solo remoldado, devido à tendência contractiva do solo gerando pressões de água nos poros, quando submetido ao corte), resultou a rotura violenta, que se processa com elevada velocidade, devido à drástica diminuição da resistência pós-rotura e ao incremento da diferença entre as forças perturbadoras e as resistentes, cuja actuação conjunta acelera o movimento da massa deslizante.

$$
\text { acelera } o=\frac{F_{w w}-F_{w}}{M}
$$

$F_{p e r i}$ - é a força perturbadora

$F_{\text {est }}^{\text {pert }}$ é a força estabilizante, a qual diminui após rotura, devido ao decréscimo da resistência com a acumulação do deslocamento

A elevada inércia desta massa deslizante levou a que todo o volume dos materiais existentes no topo do aterro se deslocasse para a base e tivesse sido retido pelo prédio, acumulando-se junto deste (fig. 11).

A existência, em planta, de uma zona de rotura mais estreita a meio do talude (fig. 9), por onde teve de passar todo o material de aterro fluidificado. funcionou como sendo um estreito, tendo produziu o ruído idêntico ao de um líquido a escorrer sob pressão.

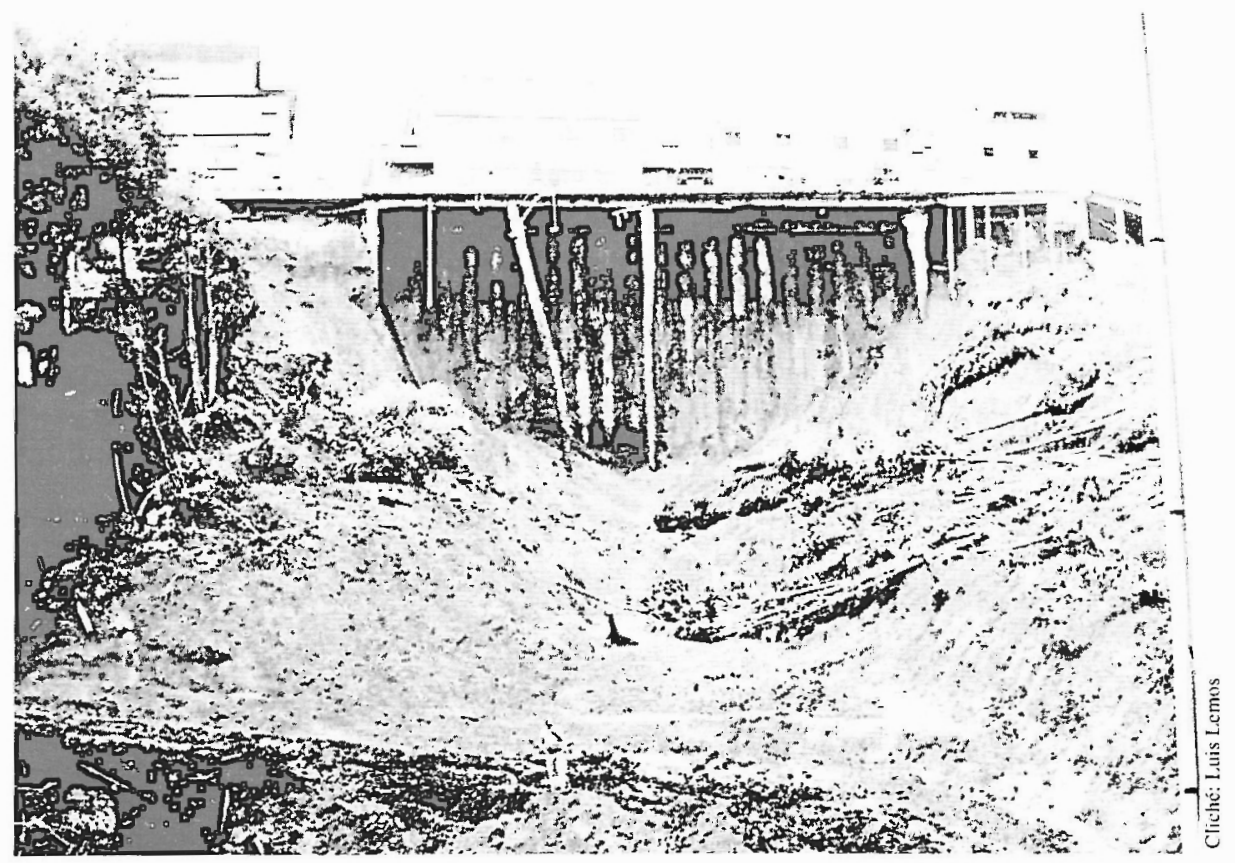

Fot. 3 - Visla geral da zona de escorregamento. 


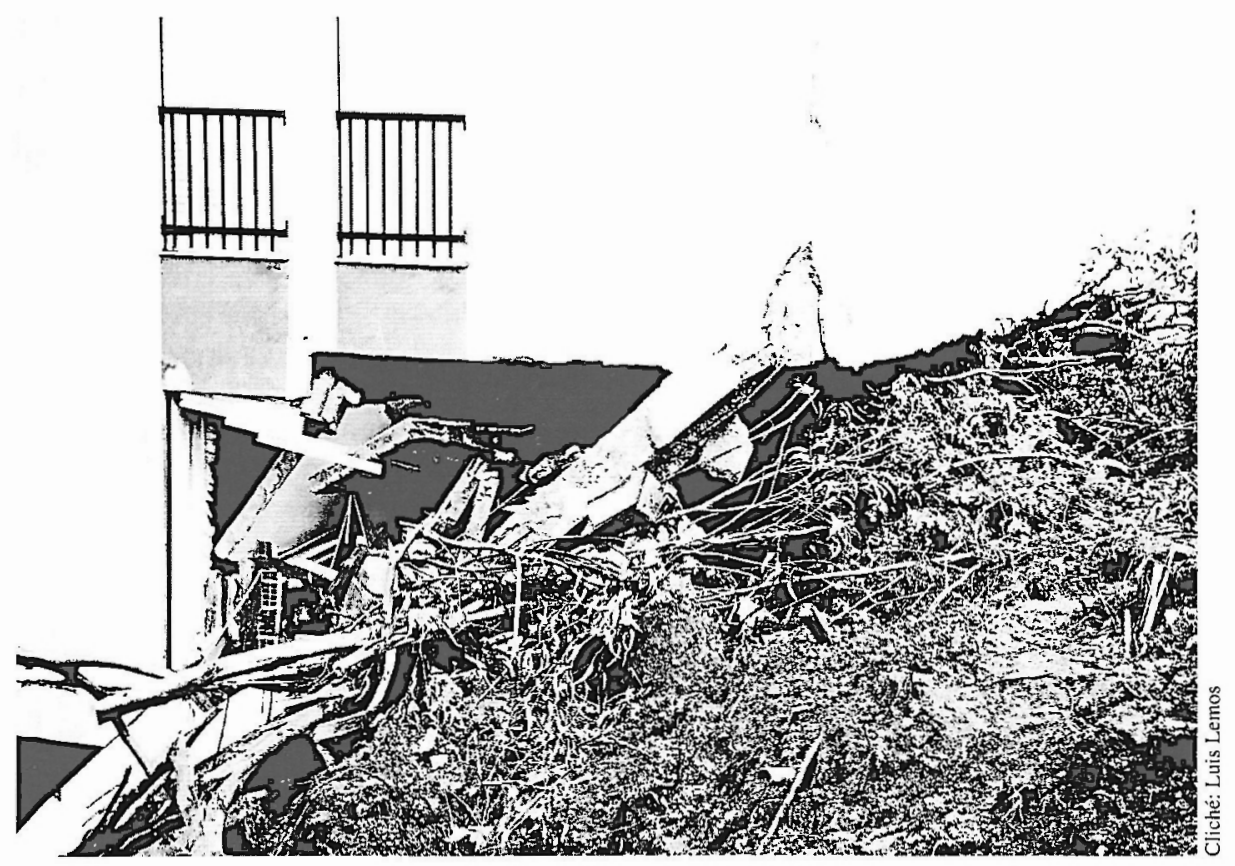

Fot. 4 - Vista do avançado do prédio com os três pilares cortados e da acumulação de terras.

\section{- Obras de consolidação da vertente}

As soluções propostas para tentar impedir a movimentação da vertente resultaram dos vários cenários criados, tendo-se optado por realizá-la em três fases, a primeira delas, com vista à estabilização da área mais afectada pelo deslizamento, a segunda para reforço da estacaria de suporte dos logradouros das vivendas e, a terceira, para consolidação geral da vertente.

As obras foram iniciadas sob condições meteorológicas muito adversas, pluviosidade abundante, sobretudo tendo em consideração que a água da chuva continuava a constituir um factor de instabilidade da vertente, além de dificultar a execução dos trabalhos.

Enquanto se procedia à abertura do estradão de acesso, os materiais de aterro situados a montante da estacaria, nos logradouros das vivendas, continuaram a movimentar-se, deslocando-se entre as estacas e depositando-se imediatamente a jusante delas, em pequenos cones, que com o tempo foram coalescendo.

Depois de se ter construído um acesso ao local, a primeira tarefa consistiu na remoção das lamas e sua substituição por pedra, de modo a construir um pedrapleno que estabilizasse toda a área situada a jusante das estacas.

Durante a construção do pedrapleno, e mesmo depois da sua conclusão, os materiais de aterro situados a montante da estacaria, continuaram a sua movimentação entre as estacas. A continuação deste processo, além da construção de novos pequenos cones, semelhantes aos anteriormente referidos, escavou verdadeiras galerias entre as estacas, que se prolongam para o interior, levando a deformações nos empedrados sobrejacentes dos logradouros.

Por outro lado, até que se realize a terceira fase, de consolidação geral da vertente, toda ela continua a movimentar-se, tendo já levado ao aparecimento de fendas nos logradouros das vivendas contíguas, não afectadas inicialmente.

Deste modo, tratando-se de um processo complexo, é de toda a urgência efectuar a totalidade da obra de consolidação da vertente, antes do próximo Outono, de modo a prevenir a repetição de situações análogas. É de realçar que algumas das intervenções ora efectuadas, nomeadamente a abertura do acesso à estacaria, veio instabilizar uma área que, antes, estava em equilíbrio precário, pelo que a terceira fase de intervenção deve contemplar uma área muito mais vasta do que a inicialmente afectada. Só assim, será possível prevenir mais danos num futuro próximo.

\section{Conclusão}

O deslizamento ocorreu a 27 de Dezembro de 2000, na encosta situada entre a Rua António Jardim e as traseiras dum prédio com 16 andares, o n 339 da $A v^{a}$ Elísio de Moura. A área afectada apresenta um desnível de cerca de $50 \mathrm{~m}$, uma largura aproximada de $60 \mathrm{~m}$ e uma extensão próxima dos $120 \mathrm{~m}$. $\mathrm{O}$ volume de terras movimentadas rondou $4000 \mathrm{~m}^{3}$ 
e arrastou o respectivo coberto vegetal, constituído essencialmente por eucaliptos de grande porte.

Foi originado pela conjugação de diversos factores, dos quais cabe aqui salientar sobretudo dois deles: por um lado, a construção de um aterro, que não respeitou as normas técnicas de execução e, por outra parte, a existência de precipitações intensas e prolongadas no tempo, traduzidas por elevados índices de pluviosidade, em particular durante os meses de Novembroe Dezembro, as quais saturaram os depósitos e provocaram a subida dos níveis freáticos no solo.

No entanto, não podemos deixar de referir que, no Inverno de 1997, já tinha ocorrido um esboço de deslizamento, na sequência do qual foram efectuadas obras de estabilização, em Julho de 1998, e que muito aumentaram a segurança de toda a encosta, pois, no Inverno de 2000 , foram elas que impossibilitaram a rotura através da superfície mais desfavorável, a formada no Inverno de 1997, a qual, a ter-se verificado e do ponto de vista das consequências, teria sido bem mais gravosa.

Com efeito, as obras efectuadas junto às vivendas da Rua António Jardim, evitaram:

- a destruição dessas vivendas;

- a destruição parcial (ou mesmo total) do prédio situado na $A v^{a}$. Elísio de Moura, pois diminuiram drasticamente o volume de terras deslocado contra o prédio;

- a perda de vidas humanas, sem dúvida, o aspecto mais importante.

O deslizamento ocorrido a 27 de Dezembro de 2000 , mobilizou uma superfície de rotura à frente das estacas que, inicialmente, se caracterizou por uma compressão das terras na base do talude e pelo aparecimento de deslocamentos significativos no topo do talude. Na zona de compressão, este processo foi evoluindo até se verificar a rotura dos terrenos que, na base do talude, constituíam a vertente.

A fragilidade do depósito de vertente e a sensibilidade não drenada dos materiais de aterro, quando saturados, implicou o aumento do momento ou força não equilibrada, tendo como consequência a aceleração progressiva da massa deslizante.

Os materiais do aterro, soltos e saturados, fluidificaram e escorreram encosta abaixo, passando através da zona mais estreita a meio da encosta, acumulando-se junto ao prédio.

\section{Agradecimentos}

Aos moradores das Rua António Jardim e $A v^{\mathrm{a}}$. Elísio de Moura, pelas muitas informações prestadas e, em particular a António Mateus, nascido e criado na propriedade que, mais tarde vendeu, foi urbanizada e onde ocorreu o deslizamento, bem como a Joaquim Fontes, um dos residentes mais antigos do Alto do Rolão (que actualmente integra a Rua António Jardim) e que, por isso, acompanhou o crescimento da urbanização e, muito especialmente aos donos de obra (Dr. A. Monteiro, Dr. J. Fontes, Dr. Crespo Couto, Prof. Doutor Carmona da Mota e Eng. F. Miraldo), pela autorização de utilização dos dados.

Ao Instituto Geofísico da Universidade de Coimbra, na pessoa do Dr. António José Alves, pelo fornecimento de elementos inéditos sobre precipitação;

Ao Dr. Fernando Gomes da Silva, pela amável cedência das fotografias que mostram o início da construção dos edifícios da Av $v^{a}$. Elísio de Moura e os jovens eucaliptos plantados para consolidar os taludes das vivendas da Rua António Jardim.

Ao Eng. Paulo da Venda, pela sua colaboração nos cálculos através do método de equilíbrio limite de Sarma.

À Câmara Municipal de Coimbra pela cedência do levantamento topográfico, feito após o escorregamento.

Ao Prof. Doutor Sarma, do Imperial College of Science and Technology da Universidade de Londres, pela cedência do programa de estabilidade de taludes.

A todos aqueles que, de algum modo, muitas vezes anonimamente, se solidarizaram com os residentes directamente afectados pelo deslizamento.

\section{Bibliografia}

AYALA CARCEDO, Francisco Javier, ANDREU POSSE, Francisco Javier, et al. (1991) - Manual de Ingeniería de Taludes, Instituo Tecnológico GeoMinero de España, Madrid, 456 p.

GANHO, Nuno, LOURENÇO, Luciano e REBELO, Fernando (1992) - "Importância da Climatologia e da Geomorfologia no Planeamento Urbano. Análise de um caso concreto na parte oriental da cidade de Coimbra". Cadernos de Geografia, Coimbra, 11, p. 75-85.

LEMOS, Luís J. L. (1997) - Estudo da estabilidade da encosta e proposta de solução. Relatório técnico (inédito);

LEMOS, Luís J. L.., LOURENÇO, Luciano e GONÇALVES, Carlos A. (2001) - "Movimentos em massa. Exemplos ocorridos no Centro de Portugal", Revista Técnica e Formativa $E n b, n^{\circ} 18$, Sintra.

LOURENÇO, Luciano (1988) - "Efeitos do temporal de 23 de Junho de 1988 na intensificação da erosão das vertentes afectadas pelo incêndio florestal de Arganil/Oliveira do Hospital". Comunicações e Conclusões, Seminário Técnicosobre Parques e Conservação da Natureza nos Países do Sul da Europa, Faro, p. 43.77 e em separata, III Semana de Geografia Física, Coimbra, $35 \mathrm{p}$. 
LOURENÇO, Luciano (1995) - "A enxurrada do ribeiro da Albagueira". Estrela Informação, 12, Parque Natural da Serra da Estrela, p. 21-22.

LOURENÇO, Luciano(1998) - "O homem, causa próxima e principal receptor das trágicas consequências do deslizamento da Lousã”, Cadernos de Geografia, Coimbra, n". 17, p. 81-88.

LYNCH, Ralph (1991) - A residual strength study of a landslip at Lousã, Portugal. Tese de Mestrado, FCTUC;
MACEDO, António (1998)-Projecto de execução das estacas, viga $e$ ancoragens. Engil (inédito).

PEDROSA, António S., LOURENÇO, Luciano e FELGUEIRAS, João (2001) - "Movimentos em massa. Exemplos ocorridos no Norte de Portugal", Revista Técnica e Formativa Enb. n 17. Sintra, p. 24-39.

REBELO, Fernando (2001) - Riscos Naturais e Acção Antrópica, Coimbra, Imprensa da Universidade. $274 \mathrm{p}$. 